\title{
ЕСЕНЦІАЛЬНІ МІНЕРАЛЬНІ РЕЧОВИНИ ЯК ЗАСОБИ КОРЕКЦІЇ ХАРЧОВОГО СТАТУСУ НАСЕЛЕННЯ, ЯКЕ МЕШКАЄ НА ТЕРИТОРІЯХ, ЗАБРУДНЕНИХ ВНАСЛІДОК АВАРІЇ НА ЧАЕС (Матеріали підготовлені до 35-річчя аварії на Чорнобильській атомній електростанції 26.04.86р.) (частина 2)
}

'MATACAР І.T., 'МОЙСЕЄНКО В.О. 'ПЕТРИЩЕНКО Л.М., 1ЧЕРНИШОВ А.В.

${ }^{1}$ ДУ “Національний науковий центр радіаційної медицини Національної академії медичних наук України", ${ }^{2}$ Національний медичний університет імені О.О. Богомольця Київ, Україна

Резюме

Ключові слова:
Вступ. Дана робота присвячена проблемі порушення харчування населення різних вікових груп, яке мешкає на територіях, радіоактивно забруднених внаслідок аварії на ЧАЕС, зокрема недостатньому вмісту макроелементів (калію, сірки, магнію, хлору) та мікроелементів (заліза).

Мета. Узагальнення відомостей про властивості есенціальних мінеральних речовин, зокрема, калію, хлору, магнію, заліза, їх добове споживання населенням різних вікових груп, яке мешкає на територіях, радіоактивно забруднених внаслідок аварії на YAEC.

Матеріали та методи. Бібліографічний - проведено теоретичний аналіз та здійснено узагальнення даних літератури, проаналізовано фактичний вміст макро- $\mathrm{i}$ мікроелементів у раціонах харчування різних вікових груп населення (дорослого працездатного, дитячого) із різних населених пунктів Іванківського району Київської області, яке мешкає на територіях, радіоактивно забруднених внаслідок аварії на ЧАЕС впродовж 2004-2018 рр. При дослідженні використано анкетно-опитувальний, математичний та статистичний методи.

Результати та їх обговорення. Особливу роль у фізіологічно оптимальному функціонуванні організму відіграють мінеральні речовини, що на рівні з іншими інгредієнтами їжі формують тканини живого організму, входять до складу ензимів та коензимів, гормонів, приймаючи участь у процесах утворення енергії, росту та відновлення організму. Утворення ферментів та реакції за їх участю відбуваються за обов'язкової участю мінеральних речовин. У хворих на хронічну хворобу нирок, анемія може призвести до серйозних проблем, ускладнити перебіг інших захворювань. Зменшення кількості гемоглобіну і (або) еритроцитів на фоні зниженого рівня заліза супроводжується збільшенням навантаження на серце. Це призводить до розвитку гіпертрофії лівого шлуночка (ГЛШ). На жаль, у багатьох пацієнтів із хворобою нирок ГЛШ виникає задовго до того, як розвивається ниркова недостатність. Часом ГЛШ навіть стає причиною смерті таких хворих. Раннє лікування анемії допомагає запобігти розвитку цього захворювання та багатьох інших серйозних ускладнень. Наявний дисмікроелементоз потребує діагностики і корекції.

Висновки. Контроль добового споживання та корекція рівнів макроелементів (калію, сірки, магнію, хлору) та інших есенціальних мінеральних речовин (зокрема, заліза) є невід'ємними складовими впродовж всього життя людини, і вкрай необхідними у населення різних вікових груп, яке мешкає на територіях, радіоактивно забруднених внаслідок аварії на ЧАЕС, особливо у осіб з віковими змінами нирок.

стан харчування, радіоактивно забруднені території, калій, сірка, магній, хлор, залізо, вік, нирки. 
Вступ. Серед факторів харчування, які мають важливе значення для підтримки здоров'я, працездатності та активного довголіття, особлива роль належить повноцінному і регулярному забезпеченню організму людини усіма необхідними макро- і мікроелементами. Макро- та мікроелементи (від мікро... і макро..., лат. elementum - стихія, первинна речовина) - хімічні елементи, що наявні в організмі у низьких (від 0,001 до $0,000000000001 \%$ та високих концентраціях. Саме це визначає їхні назви: до макроелементів відносяться речовини, концентрація у \% до маси тіла 0,1-0,9 (калій, хлор) та 0,01-0,09 (магній), до мікроелементів - 0,001-0,009 (залізо), які $€$ поживними речовинами [1-9].

Особливу роль у фізіологічно оптимальному функціонуванні організму відіграють мінеральні речовини, що на рівні з іншими інгредієнтами їжі формують тканини живого організму, входять до складу ензимів та коензимів, гормонів, приймаючи участь у процесах утворення енергії, росту та відновлення організму. Утворення ферментів та реакції за їх участю відбуваються за обов'язкової участю мінеральних речовин $[10,11,12]$. Без них не відбуваються підтримка кислотно-лужної рівноваги, не створюється фізіологічно необхідна концентрація іонів у клітинках організму та у міжклітинній рідині; вони генералізують та проводять нервові імпульси, діють як каталізатори хімічних процесів, регулюють активність ферментів тощо [13-18].

Мінеральні речовини внутрішньоклітинної та міжклітинної рідин впливають на гомеостаз, остеогенез, приймають участь у процесах росту та відновлення організму, регулюють функціонування нервової системи та впливають на м'язовий тонус, що має надзвичайне значення для роботи серцево-судинної системи.

Метою дослідження $\epsilon$ узагальнення відомостей про властивості мінеральних речовин (калій, сірка, магній, хлор, залізо), добове споживання населенням різних вікових груп, яке мешкає на територіях, радіоактивно забруднених внаслідок аварії на ЧАЕС.

Матеріали і методи. Для досягнення поставленої мети використано такі матеріали і методи: бібліографічний - проведено теоретичний аналіз та здійснено узагальнення даних літератури, проаналізовано фактичний вміст макроелементів у раціонах харчування різних вікових груп населення (дорослого працездатного, дитячого, вагітних жінок) із різних населених пунктів Іванківського району Київської області, яке мешкає на територіях, радіоактивно забруднених внаслідок аварії на ЧАЕС впродовж 2004-2018 рр. При дослідженні використано анкетно-опитувальний, математичний та статистичний методи.

Результати та їх обговорення. Чорнобильська катастрофа - техногенна екологічно-гума- нітарна катастрофа, спричинена двома тепловими вибухами і подальшим руйнуванням четвертого енергоблока Чорнобильської атомної електростанції, розташованої на території України (колишньої УРСР), в ніч на 26 квітня 1986 року.

У хворих на хронічну хворобу нирок, анемія може призвести до серйозних проблем, ускладнити перебіг інших захворювань. Зменшення кількості гемоглобіну і(або) еритроциті супроводжується збільшенням навантаження на серце. Це призводить до розвитку гіпертрофії лівого шлуночка (ГЛШ). На жаль, у багатьох пацієнтів із хворобою нирок ГЛШ виникає задовго до того, як розвивається ниркова недостатність. Часом ГЛШ навіть стає причиною смерті таких хворих. Раннє лікування анемії допомагає запобігти розвитку цього захворювання та багатьох інших серйозних ускладнень. Наявний дисмікроелементоз потребує діагностики і корекції.

Калій (лат. каlium), К. Атомний номер в періодичній системі елементів Д. І. Менделєєва - 19. Поряд із натрієм, магнієм та кальцієм відноситься до основних електролітів, що присутні в організмі людини. Калій $є$ основним внутрішньоклітинним катіоном. Він відповідає за водний баланс в організмі і підтримує осмотичний тиск, сприяє функціонуванню нервової та серцево-судинної систем, впливає на кислотно-лужний баланс організму і відіграє важливу роль в обміні вуглеводів [11, 12].

Найбільш важливі функції калію в організмі:

- контроль над регулюванням артеріального тиску;

- підтримує водно-електролітний та кислотнолужний баланс;

- регулює кількість іонів та воду в клітинах;

- сприяє нормальному функціонуванню нирок.

- регулює проведення імпульсів через нейрони.

Норма калію в сироватці крові коливається від 3,5 до 5,0 ммоль/л. Однак при наступних концентраціях спостерігається:

- легкий дефіцит - 3,5-3,0 ммоль/л;

- помірний дефіцит - 3,0-2,5 ммоль/л;

- виражений дефіцит <2,5 ммоль/л;

- легкий надлишок - 5,5-5,9 ммоль/л;

- помірний надлишок - 6,0-6,4 ммоль/л;

- сильний надлишок > 6,5 ммоль/л.

У разі дефіциту калію, тобто гіпокаліємії, в організмі можуть виникати наступні розлади:

- аритмія;

- гіпертензія;

- запаморочення;

- затримка води в організмі;

- м'язові спазми;

- непереносимість глюкози;

- нервозність;

- поява набряків на ногах;

- слабкість;

- сонливість. 
Причину дефіциту калію важко точно встановити. Однак фахівці виділяють групу провокуючих чинників, зокрема:

- анорексія або недоїдання;

- великі опіки;

- вживання великої кількості кави.

- застосування ліків з групи діуретиків (наприклад, фуросеміду);

- захворювання нирок та надниркових залоз (хвороба Аддісона), синдром Кушинга;

- перебування на дієті з низьким вмістом калію;

- споживання бета-агоністичних протиастматичних препаратів;

- хронічна діарея або блювота.

На думку фахівців, оптимальне або мінімальне надходження калію з їжею для здорових та хворих людей ще не визначено. В організмі людини міститься приблизно 160-250 г калію ( 0,22\% від загального вмісту в організмі, через що його відносять до макроелементів). Добова потреба людини в калії становить 2-3 г. Його концентрація в організмі залежить від віку та статі людини.

У 2013 році Всесвітня організація охорони здоров'я (ВООЗ) випустила рекомендації відповідно до яких щоденне споживання калію здоровими людьми (з нормальною функцією нирок) має становити, в середньому, 3,51 г/день. Відповідно із зазначеним добова потреба в калії має бути:

- д для дітей (до 3 років) - 3 г;

- для дітей (4-8 років) - 3,8 г;

- для дітей та підлітків (9-18 років) - 4,5 г;

- для дорослих (старше 18 років) - 4,7 г.

За результатами наших досліджень встановлено, що вміст калію у раціонах харчування обстежених вагітних жінок, які мешкають у екологічно небезпечних внаслідок аварії на ЧАЕС регіонах становив $71 \%$ від фізіологічних потреб. Щодо інших вікових груп дорослого населення, то надходження з раціоном харчування калію у чоловіків було вищим за фізіологічні потреби на $16 \%$, а у жінок на $13 \%$ менше норми $[19,20]$.

Вміст калію у харчуванні дітей, які мешкають в екологічно небезпечних регіонах України, задовольняв фізіологічної потреби на 77 \% [21].

Деякі органічні сполуки калію застосовують в медицині (калій ацетат, калій аспоролінат, калій оротат) і неорганічні (калій хлорид) його солі. Останні підтримують водний баланс, регулюють розподіл води в органах та системах організму, впливають на осмотичний тиск та кислотнолужну рівновагу, збуджують м'язову і нервову тканин.

В великих кількостях калій знаходиться в рослинних продуктах, особливо в абрикосах, персиках, апельсинах, бананах, ананасах, картоплі, помідорах, капусті, моркві.
Крім продуктів харчування, у разі гострого дефіциту калію, можна застосовувати біологічно активні добавки, які, як правило, випускаються у комплексі з магнієм та вітаміном В6. Однак, перед їх вживанням, необхідно проконсультуватися з лікарем і підібрати оптимальний варіант дозування.

Сірка (лат. sulfuris), S. Атомний номер у періодичній системі елементів Д. І. Менделєєва 16. Цей макроелемент відноситься до біогенних органічних сполук і відіграє важливу роль в організмі людини, зокрема:

- бере участь в обміні речовин;

- впливає на згортання крові;

- входить до складу цистину та метіоніну;

- сприяє виділенню жовчі;

- підвищує проникність мембран;

- приймає участь в утворенні ряду ферментів, виробленні енергії та синтезі колагену;

- проявляє протиалергійну дією;

- сприяє надходженню в клітини поживних речовин;

- покращує роботу мозку;

- стимулює клітинне дихання [11, 12].

Сірку ще називають «мінералом краси». В організмі людини ця речовина міститься головним чином у шкірі (меланин та кератин), а також у тканинах нервової системи, м'язах, хрящах, кістках, суглобах, волоссі та нігтях.

Дієтологи стверджують, що найбільша концентрація сірки міститься у перепелиних яйцях (якщо тварини вільного вигулу). Багато цієї речовини знаходиться також у курячих яйцях, сирі, рибі, м'ясі, крупах, хлібі, брюссельській і звичайній капусті, бобових, цибулі, часнику, ріпі, салаті, пророслій пшениці.

Дефіцит сірки в організму проявляється рідко і може виникнути лише у людей, які зовсім не вживають білкової їжі тваринного походження.

Вважається, що добова потреба для людини у сірці складає 500-1000 мг, за іншими даними 3-4 г, і ця величина повністю задовольняється раціональним харчуванням. У групі ризику з дефіцитом сірки - люди, які харчуються недостатньо та одноманітно і споживають фосфати - лимонади, консерви, ковбаси тощо.

Нашими дослідженнями не встановлено дефіциту чи профіциту цього елементу.

При нестачі сірки знижується життєвий тонус, організм швидше старіє, шкіра стає в'ялою, волосся позбавляється блиску, нігті тоншають.

Дефіцит сірки супроводжується різким зниженням імунітету. Людина частіше хворіє інфекційними, вірусними чи грибковими захворюваннями. Швидка стомлюваність переходить у хронічне втому. Дефіцит сірки підвищує рівень жиру і цукру в крові. 
Про надлишок сірки в організмі, на даний період часу, нічого не відомо, так як цей макроелемент в їжі міститься в нетоксичних для людини кількостях.

Надлишок свинцю, ртуті, кадмію підсилює дефіцит сірки. У ліквідаторів чорнобильської аварії відносно часто зустрічалось порушення співвідношення $\mathrm{S} / \mathrm{Cd}, \mathrm{S} / \mathrm{Pb}, \mathrm{S} / \mathrm{Hg}$ у бік дефіциту сірки. Сірка здатна утворювати SH-групи, що забезпечують захист організму від радіаційного ураження, зв'язуючи токсичні продукти метаболізму. Ендогенна сірчана кислота, що утворюється в організмі приймає участь у знезараженні отруйних речовин - фенола, крезола, індола, що виробляються мікрофлорою кишківника із амінокислот. Також сірчана кислота зв'язує численні лікарські препарати та їх метаболіти, утворюючи кон'югати, які виводяться із організму 3 сечею.

Сірка виводиться з організму з сечею (60\%) та калом (30\%). До 10 \% виходить через легені і шкіру у формі сірководню, що надає поту та іншим виділенням неприємного запаху.

В медицині сірка використовується у вигляді лікарських препаратів, які містять елементарну сірку, яка сама по собі в фармакологічному відношенні практично пасивна. Однак при взаємодії з деякими органічними речовинами в організмі утворюються сполуки, що проявляють фармакологічний ефект.

До препаратів, які використовуються в медичній практиці відносять лікарські засоби, що вміщують очищену і осаджену сірку. Для зовнішнього застосування випускають очищену сірку, наприклад, сірко-карталону, пасту сірко-цинкокарталону тощо.

Сірка знімає судоми, зменшує запалення і біль при розтягненнях, артритах, бурситі, міозиті.

Самолікування медичними препаратами без консультації з лікарем і підбором оптимального дозування небезпечне!

Хлор (кhlorum), СІ. Атомний номер в періодичній системі елементів Д. І. Менделєєва 17. Цей макроелемент бере участь у регуляції осмотичної рівноваги і впливає на обмін, регулюючи та підтримуючи в організмі водно-сольовий баланс. Від 30 до 60 \% хлору сконцентровано, головним чином, у шкірі. Також він входить до складу міжклітинних рідин, крові та кісткової тканини. В організмі міститься до одного кілограма іонізованого хлору та в елементарному вигляді, в середньому, 95 г. Цей макроелемент містить соляна кислота шлунку (головна складова шлункового соку), яка обумовлює травлення їжі. Йони хлору необхідні для здорового функціонування нервової та м'язової систем. Хлор допомагає виводити з організму шлаки, токсини, вуглекислий газ, бере участь у регуляції вмісту жиру в печінці. Він необхідний для роботи головного мозку, при- ймає участь в контролі стану еритроцитів, бере участь у формуванні плазми крові $[11,12]$.

За добу людина з їжею споживає від 5 до 10 г хлору (кухонна сіль, буряки, злакові, бобові, овочі, фрукти, м'ясо, яйця). Багаті на хлор морепродукти, зокрема морська риба (мойва, скумбрія, хек, карась, горбуша, тунець, камбала).

Хлор сприяє знищенню патогенних мікроорганізмів, грибів та вірусів. Іони хлору, регулюючи водно сольовий обмін в організмі, відіграють важливу роль в процесі транспорту іонів через біологічні мембрани, утворюючи біоелектричні потенціали.

Добова потреба людини в іонах хлору становить приблизно 215 ммоль. У перерахунку на атомарний хлор, 300-800 мг/добу задовольнить потребу дітей молодшого віку у цьому елементі; 1100-2300 мг/добу буде достатньою для дітей підліткового віку і 2300 мг/добу для дорослих людей.

При нестачі в організмі хлору виникає сонливість, слабкість м'язів, втрата апетиту, ослаблення пам'яті, сухість у роті, спостерігається випадіння волосся та зубів (при глибокому дефіциті).

Надмірна кількість хлору в організмі шкідлива, оскільки сприяє затриманню води в органах і тканинах, що загрожує підвищеним тиском, болями в грудях і голові, сухим кашлем, диспепсичними розладами, різзю в очах та сльозотечею. У більш важких випадків передозування хлором, можливий розвиток бронхопневмонії (супроводжується підвищеною температурою) і токсичного набряку легенів.

Надлишок хлору в організмі рідко зустрічається, тому що він виводиться з сечею і потом.

В медичній практиці препарати хлору використовують як дезінфікуючі та антисептичні засоби. В якості таких засобів використовується хлороактивні та хлоровмісні сполуки зокрема:

- гіпохлорид калію та літію;

- хлорну воду;

- хлоропрохідні ізоціанорової кислоти та їх солі.

В якості антисептиків використовують антиформін, алоромін Б, пантоцид, хлорне вапно.

Хлор у чистому вигляді, а також хлоровмісні сполуки токсичні для організму людини!

Магній (лат. мagnesium), Mg. Атомний номер в періодичній системі елементів Д. І. Менделєєва 12. Магній задіяний у більш ніж 300 біохімічних реакціях, що відбуваються в організмі людини. Він бере участь в енергетичному обміні та синтезі білків, допомагає нормальній роботі м'язової та нервової систем, підтримує стійкий ритм серця та здоров'я імунної системи, а також сприяє збереженню кісток міцними $[11,12,35]$.

Це однин із важливих біоелементів, які активують ферментативні процеси, зокрема магній 
регулює реакції фосфорного обміну, гліколізу, приймає участь у багатьох етапах синтезу білків, жирних кислот і ліпідів, залучається до утворення і розпаду нуклеїнових кислот.

Магній допомагає регулювати рівень цукру в крові, сприяє нормалізації артеріального тиску, бере участь у синтезі колагену [36].

Магній в організмі потрібен для:

- вироблення енергії (АТФ) та засвоєння фосфору, калію, вітамінів групи В, С, Е в кишечнику;

- запобігання утворення каменів у нирках, жовчному міхурі та подагри;

- здорового імунітету та зниження ризику розвитку деяких ракових захворювань;

- здорового серцевого ритму;

- зміцнення кісток, профілактики остеопорозу;

- зниження ризику розвитку цукрового діабету (при споживанні 300-365 мг магнію посилюється чутливість тканин до інсуліну);

- нормальної роботи кишечника, профілактики запорів та спричиненої ними хронічної інтоксикації;

- підвищення стійкості організму до стресу;

- профілактики атеросклерозу та гіпертонії.

Після натрію, калію та кальцію магній $€$ одним із найбільш поширених неорганічних катіонів в організмі людини - його сумарна маса складає приблизно 25 г. Найбільша кількість магнію (60\%) міститься в кістках, де він разом з кальцієм приймає участь у формуванні їх основи. В тканинах із найбільш інтенсивними обмінними процесами сконцентрована 1/3 цього макроелементу (м'язи, нервова тканина). Найбільший його вміст зафіксовано в міокарді.

Під час вагітності достатня насиченість організму магнієм відіграє особливу роль, оскільки, будучи природним антагоністом кальцію, він сприяє пригніченню надмірної активності гладкої та попереково-смугастої мускулатури, у тому числі і матки. При недостатньому надходженні в організм магнію у вагітних може розвинутися прееклампсія з одночасним підвищенням артеріального тиску, що створює ризик загрози переривання вагітності та передчасних пологів.

Більшість людей вживає мінімум в два рази менше магнію, ніж це потрібно для нормального функціонування організму (табл. 1). Потреба у магнії зростає при стресових та фізичних навантаженнях, які відчуває людина внаслідок сучасного способу життя, при патологічних станах та захворюваннях, а також в спеку, при вагітності і лактації, під час відвідування сауни, при зловживанні алкоголем, перебуванні на незбалансованих обмежувальних дієтах і синдромі хронічної втоми, при вживанні ряду лікарських засобів, що швидко виснажують запаси магнію [37-43].
Таблиця 1

Середньодобові потреби людини в магнії, мг

\begin{tabular}{|l|c|}
\hline \multicolumn{1}{|c|}{ Вікова група } & Норма вживання \\
\hline до 12 місяців & $55-70$ \\
\hline від 1 до 3 років & 150 \\
\hline від 4 до 6 років & 200 \\
\hline від 7 до 10 років & 250 \\
\hline від 11 до 17 років & 300 \\
\hline Дорослі & $300-500$ \\
\hline
\end{tabular}

Всесвітньою організацією охорони здоров'я (ВОО3) дефіцит магнію визнано нозологічною одиницею захворювань людини за міжнародною класифікацією хвороб (MKX-10). Нестача магнію в організмі $\epsilon$ досить поширеним явищем. Спостерігається майже у 16-42 \% людей. При цьому клінічні ознаки виявляються все частіше. Причинами цього є:

- дефіцит вітамінів $\mathrm{B}_{1}, \mathrm{~B}_{2}$ і $\mathrm{B}_{6}$, зловживання алкоголем, куріння, застосовування проносних засобів, діуретиків, гормональних та протизапальних ліків, деяких антибіотиків;

- дефіцит магнію в ґрунті та воді і, відповідно, в рослинних продуктах;

- надмірне вживання рафінованих продуктів, зокрема, виробів з білого борошна, каш швидкого приготування;

- недостатнє вживання натуральної їжі, багатої магнієм (горіхів, насіння, висівок та ін.);

- незбалансованість монодієт, надмірне вживання жирної їжі.

За нашими дослідженнями, вміст магнію у раціонах харчування вагітних жінок, які мешкають у екологічно небезпечних регіонах України становив від 75 до 78 \% від фізіологічних норм. Раціони харчування чоловіків в середньому вміщували магнію 87 \% від фізіологічних норм, тоді як раціони харчування жінок в середньому вміщували магнію на 9 \% більше від фізіологічних норм [19, 20].

Щодо дітей, то вміст у раціонах магнію також на 19-23 \% було вищим від фізіологічних потреб [21].

Значну частину запасів магнію організм витрачає на боротьбу із забрудненим повітрям, їжі пестицидами, стрес, порушеним обміном речовин (ожиріння, цукровий діабет, ішемічна хвороба серця, інфаркт міокарда, ПМС тощо).

Крім того, виснажують запаси магнію запальні захворювання шлунку та кишківника, захворювання щитоподібної залози, хронічний стрес, спортивні навантаження, вагітність та годування грудьми. 
Прояви магнієвого дефіциту різноманітні, але можна впевнено сказати, що присутня проблема при:

- «перебоях» у роботі серця, підвищеному тиску крові (50 \% пацієнтів з гіпертензією страждають від дефіциту магнію);

- вираженому передменструальному синдромі, судомах під час вагітності;

- дратівливості, поганому сні, погіршенні пам'яті, уваги, депресії, головних та мігренеподібних болях та при відчутті нестачі повітря;

- закрепах, нудоті, безпричинних болях у животі;

- карієсі зубів;

- підвищенні «поганого» холестерину (ліпопротеїдів низької щільності);

- спазмі м'язів (у тому числі нічні судоми литкових м'язів);

- хронічних болях у шиї та спині;

- схильності до набряків;

- утворення каменів у нирках та жовчному міхурі.

Сполуки магнію, а особливо їх солі, використовуються в медицині у вигляді лікарських засобів. Існуючі препарати магнію не завжди засвоюються організмом належним чином.

У залежності від розчинності у воді лікарські препарати магнію ділять на 2 групи:

- добре розчинні (магній сульфат, магній тіосульфат, магній аскорбінат);

- практично нерозчинні (магній карбонат, магній трисилікат).

На ЦНС препарати магнію, добре розчинної групи, діють негативно (пригнічують діяльність ЦНС, викликаючи снодійний, наркотичний та протисудомний ефекти). Токсична дія препаратів проявляється в послаблені дихання та знижені тонусу скелетних м'язів. На серцево-судинну систему препарати магію проявляють гіпотензивний ефект, зменшуючи ударний та хвилинний об'єм серця. Ці наслідки проявляються при парантеральному введенні лікарських засобів із вмістом магнію.

Препарати магнію практично нерозчинні у воді призначаються в основному per os.

Важливо пам'ятати, що нормальний рівень магнію у крові не $є$ прямим показником рівня магнію в клітинах організму і не виключає його дефіцит в організмі.

Про те, що в організмі дефіцит магнію сигналізують наступні симптоми:

- відчуття оніміння, поколювання;

- м'язові скорочення та судоми.

- втрата апетиту;

- головні болі;

- приливи жару;
- порушення серцевого ритму;

- постійна втома.

Найкращими природними джерелами магнію (Мг на 100 г) є насіння - кунжуту (540), висівки пшеничні (448), насіння соняшника (317), крупа гречана (200), крупа вівсяна (116), халва: тахінноарахісова (243), соняшникова (178). Також багато магнію містять чорний шоколад (133) та сухе молоко знежирене (160).

У великих кількостях магній можна знайти у продуктах рослинного походження, зокрема у горіхах (мг на 100 г) - кеш'ю (270), кедрові (251), мигдалю (234), фундук (160). Саме цими продуктами при здоровому харчуванні рекомендують робити перекуси між прийомами їжі. Тут теж варто пам'ятати про кількість: достатньо кількох горішків та 20-30 насінин для отримання достатньої кількості магнію. Добрими перекусами $€$ також фрукти (магній знаходиться під шкіркою, тому їх краще не очищувати) та сухофрукти. Банани містять багато магнію у самій м'якоті.

Бобові та злаки є незамінним джерелом цього важливого для життя макроелементу. Чимало магнію містить зелень та овочі. Особливо корисно для поповнення магнію вживати морську капусту, помідори, моркву. Усі продукти з вмістом магнію гарно між собою поєднуються, і з них можна приготувати смачні та дуже корисні страви. Але слід пам'ятати, що зловживати, навіть корисними продуктами не варто!

Залізо (ferrum), Fe. Атомний номер в періодичній системі елементів Д. І.Менделєєва 26. Відповідно до класифікації залізо відноситься до есенціальних макроелементів. Залізодефіцитні стани серед населення планети Земля зустрічаються дуже часто. Тому нестачу заліза справедливо можна віднести до найбільш розповсюджених дефіцитів, що викликають анемію $[44,45,46]$.

Анемія відноситься до провідних проблеми, профілактикою яких переймається ВООЗ. Відповідно аналізу результатів епідеміологічних спостережень, на кінець минулого сторіччя, в світі більше 3,85 мільярда населення страждає на залізодефіцитні анемії, для лікування якої витрачається найбільше коштів, за винятком туберкульозу. Більш ніж у третини жінок репродуктивного віку та майже у 50\% дітей перших років життя діагностується недокрів'я. В країнах Європи та США розповсюдженість недокрів'я серед новонароджених коливається від 7 до 12\%. В країнах з нерозвинутою економікою цей показник складає 56\% (вагітні), жінки фертильного віку - 44\%, діти шкільного віку - 42\%, серед школярів - кожна друга дитина [47-55].

Залізо їжі поділяється на гемове (у складі гема) і негемове. Між цими формами $є$ відмінності (табл. 2). 
Відмінності між гемовим і негемовим залізом

\begin{tabular}{|l|c|c|}
\hline \multicolumn{1}{|c|}{ Залізо } & $\begin{array}{c}\text { Гемове залізо } \\
\text { (у поєднанні з білком) }\end{array}$ & $\begin{array}{c}\text { Негемове залізо } \\
\text { (іонізоване) }\end{array}$ \\
\hline Доля у звичайному раціоні & $10-15 \%$ & $85-90 \%$ \\
\hline Вміст у м'ясних продуктах & $40 \%$ & $60 \%$ \\
\hline Вміст у рослинних продуктах & Відсутнє & 100\% \\
\hline Усмоктуваність в ШКТ & до 20-30\%! \\
\hline $\begin{array}{l}\text { Залежність засвоєння від контролюю- } \\
\text { чого впливу слизової кишківника }\end{array}$ & менше & більше \\
\hline Взаємний вплив на засвоєння заліза & $\begin{array}{c}\text { Посилює всмоктування } \\
\text { негемового заліза }\end{array}$ & $\begin{array}{c}\text { не впливає на всмоктуван- } \\
\text { ня гемового заліза }\end{array}$ \\
\hline
\end{tabular}

Основне джерело гемового заліза - це м'ясні продукти. Із яловичини, свинини і м'яса кролика засвоюється від 15 до 30 \% гемового заліза, менше - із курячого м'яса і печінки (10-20 \%). Більше всього гемового заліза у телятині, кров'яних ковбасах і у сальтисон. Багато заліза знаходиться в рослинних продуктах, зокрема: квасолі, вівсяній та гречаній кашах, петрушці, білокачанній капусті, сушених фруктах, какао, сезамі та грибах. Однак таке залізо засвоюється при високому вмісті у раціоні аскорбінової кислоти.

В організмі людини середньої ваги міститься приблизно 50 г заліза. Виділяють три «депо» гемового заліза, зокрема:

- д до 60 \% від загального вмісту гемового заліза в організмі міститься в гемоглобіні циркулюючих еритроцитів;

- в клітинах м'язів (в меншій кількості) міститься також залізо у вигляді міоглобіну. В печінці та селезінці знаходиться найбільш цінне для організму гемове залізо (в еритроцитах, що зруйнувались);

- окрім зазначеного, в організмі $є$ відносно постійне депо гемового заліза, що міститься в феритині (молекули білку, котрі зв'язують залізо при його надлишку в організмі і при необхідності віддають його тканинам).

Гемове залізо виконує важливу функцію постачає клітинам організму кисень і забирає у них вуглекислий газ. Залізо, що міститься в дихальних пігментах, гемоглобіні та метгемоглобіні окрім дихальної функції стимулює роботу кровотворних органів.

Залізо також входить до складу білків, ферментів та контролює обмін холестерину, виконує роль детоксиканту в печінці при утворені вільних радикалів, приймає участь при синтезі ДНК, впливає на якість імунної відповіді при інфекційних та вірусних враженнях організму, відіграє важливу функцію в окислювально-відновлювальних реакціях та енергетичному обміні клітин.
Залізо приймає участь в побудові сполучної тканини. При неактивній фазі ревматизму концентрація заліза незначно зростає або знаходиться в межах норми. Коли ж деструкція сполучної тканини замінює її організацією (в процесі антиревматичної в продуктивній фазі ревматизму) то залізо більш витрачається на дільниці зміненої сполучної тканини.

Фізіологічна норма надходження заліза з харчовими продуктами для дорослої людини становить 15 мг на добу. Прийнято вважати, що на гемову форму заліза припадає 40 \% заліза всіх продуктів тваринного походження. У здорових людей рівень засвоєння заліза коливається від $1 \%$ при рослинній дієті до 10-25 \% при м'ясній [56].

Раціони, які містять достатньо або іноді навіть надлишкову кількість заліза, не завжди можуть повністю задовольняти потребу в ньому здорових людей. Склад раціонів може відігравати важливу роль у розвитку недостатності заліза. Частота випадків залізодефіцитної анемії може підвищуватись серед людей з нормальним або підвищеним споживанням заліза навіть при вживанні раціонів, які містять відносно багато білків рослинного походження.

Основне джерело надходження заліза до організму людини - це харчові продукти, переважно тваринного походження. В рослинних продуктах залізо міститься у вигляді комплексів з органічними кислотами, вуглеводами та рослинними білками, тому в організмі людини погано засвоюється. 3 тваринної їжі залізо у вигляді гемоглобіну, міоглобіну, ферритину та гемосидерину печінки та селезінки (засвоюється краще). Доречно, жінки засвоюють залізо в 4 рази краще ніж чоловіки. Організм дітей першого року життя поглинає 70 \% заліза, що надійшло до їх організму. У дітей до 10 років - $10 \%$, а у дорослих до 3 \%. Найгірше залізо засвоюється організмом людей старшого та похилого віку. 
Інгредієнти їжі суттєво впливають на засвоєння заліза із раціону харчування людини. Сприяють всмоктуванню заліза:

- кальній, аскорбінова кислота, соляна кислота, такі амінокислоти як цистеїн та метіонін;

- наявність в овочевому раціоні харчування м'яса (достатньо 50 грамів сприяє всмоктуванню заліза в два ризи), риби (100 грамів риби сприяє зростанню засвоєння заліза в 3 рази) та фруктів з великим вмістом вітамін С (зростає всмоктування в 5 разів).

Ускладнюють всмоктування заліза:

- фосфор, фітин, трьохвалентне залізо, понижена кислотність шлунку;

- при вживані чаю, залізо злакових, м'яса та із змішаних раціонів всмоктується набагато гірше, через блокування мікроелементу таніном, що міститься в чаї і утворення нерозчинних комплексів залізо-танін.

Залізо м'яса всмоктується на 40-50 \%, а риби лише на $10 \%$. Найбільш легко всмоктується залізо, що міститься у печінці. Засвоєння заліза із раціону не залежить від його вмісту в окремих харчових продуктах рослинного походження.

Втрати заліза організмом відбуваються різними шляхами. Із сечею виводиться лише до $1 \%$ добової потреби. У тонкому кишківнику, де відбувається інтенсивний обмін клітинного фонду заліза, через велику поверхню органу втрачається до 90 \% від його вмісту в організмі (до 5 \% з відмерлим епітелієм та до 85 \% в каловими масами).

Рівень заліза в організмі людини не постійний. Зруйнувавшись у печінці та селезінці (приблизно 25 мг на добу) до 90 \% знову всмоктується та використовується організмом повторно для утворення еритроцитів.

Ознаки порушення обміну заліза характеризуються наступними симптомами:

- анемія (недокрів'я);

- деформоване харчування (дієти, вживання крейди, піску, глини тощо);

- швидка стомленість;

- низька здатність до навчання;

- мерзлякуватість (через зниження температури тіла);

- зниження фізичної та розумової працездатності;

- пониження функції щитоподібної залози;

- деформація нігтів;

- змінення поверхні язиці та порушення смакових відчуттів;

- підвищена дратівливість, плаксивість, болі при менструації.
Частіше всього дефіцит заліза відмічається:

- при незбалансованому харчуванні (надлишок борошняних продуктів у раціоні);

- у недоношених дітей;

- у жінок фертильного віку;

- у дітей, котрі знаходяться на штучному вигодовуванні;

- у дітей підліткового віку;

- у людей похилого віку;

- у хворих, котрі мають хронічні кровотечі (наприклад, шлунково-кишкові тощо);

- при затяжних чи рясних місячних, тощо.

Залізо і мідь проявляють синергічну дію.

В організмі пацієнтів, котрі страждають на хронічну ниркову недостатність та ревматичний артрит, залізо може накопичуватись у небезпечних кількостях. Тривале вживання значної кількості продуктів із високим вмістом заліза може призвести до бронзової хвороби, діабету, враженню печінки, імпотенції та проблем із серцем.

Ранні ознаки передозування заліза: діарея із кров'ю, сильна нудота, блювання кров'ю, біль у животі.

Пізні ознаки - слабкість, колапс, блідість шкіряних покровів, синюшність губ, нігтів, поверхневе дихання, слабке серцебиття тощо.

Надлишок заліза в організмі призводить до ризику ракових захворювань та ішемічної хвороби серця.

Звичайний раціон містить біля 18 мг заліза. При цьому всмоктується його тільки 1-1,5 мг. При дефіциті заліза в організмі всмоктування збільшується до 2,3-3,0 мг, але не більше.

За даними наших досліджень встановлено, що вміст заліза у раціонах харчування вагітних жінок становив в середньому $85 \%$ від фізіологічних потреб. Щодо інших категорій дорослого населення, то спостерігався профіцит цього нутрієнту. Так, раціони чоловіків вміщували заліза в середньому на $18 \%$, а жінок - на 13\% більше від фізіологічних норм $[19,20]$. Раціони дітей також вміщували в середньому на $11 \%$ більше від фізіологічних норм [21].

Про наявність в організмі достатньої кількості заліза можна стверджувати на підставі двох важливих показників: насичення трансферину залізом (TSAT) і вмісту феритину. Критерії наявності в організмі достатньої кількості заліза для досягнення бажаного рівня гемоглобіну: n TSAT щонайменше $20 \%$; n вміст феритину щонайменше 100 нг/мл.

Хронічна хвороба нирок має п'ять стадій, які визначають на підставі ступеню їх ураження i швидкості клубочкової фільтрації (ШКФ). За ШКФ оцінюють, наскільки добре функціонують нирки. Анемія виникає тоді, коли в організмі зменшується кількість червоних кров'яних тілець. Червоні кров'яні тільця переносять кисень із легень у всі 
інші частини тіла, забезпечуючи організм енергією для життєдіяльності. Анемія може бути причиною виникнення низки симптомів

- Блідість

- Відчуття втоми

- Слабкість і нестача сил для повсякденної роботи

- Зниження апетиту

- Неспокійний сон

- Зниження розумової активності

- Запаморочення або біль голови

- Прискорене серцебиття

- Задишка

- Депресія або пригнічений настрій.

Однією з причин розвитку анемії у хворих з XXH $€$ низький вміст в організмі заліза, вітаміну В12 або фолієвої кислоти.

Крім того, нирки виробляють важливий гормон під назвою еритропоетин (ЕРО). Гормони - це речовини, які виробляються в організмі і підтримують його життєдіяльність і здоров'я. ЕРО стимулює утворення еритроцитів. Якщо у вас хронічна хвороба нирок, ЕРО виробляється у недостатній кількості. Це призводить до зниження кількості червоних кров'яних тілець і анемії. Анемія розвивається майже у всіх пацієнтів із хворобами нирок. Вона може виникати уже на початкових стадіях хвороби нирок і поступово прогресувати в міру погіршення функції нирок і зниження їх спроможності виробляти EPO.

Для пацієнтів, які мають ураження нирок необхідно довгострокове спостереження. У спостереженні пацієнта повинен брати участь сімейний лікар, нефролог та інші фахівці. При XXH 1-3-ї стадій головні заходи - це регулярний контроль функції нирок і деяких інших аналізів (аналіз сечі, гемоглобін, калій, натрій, сечова кислота, електроліти крові і ін.). Якщо ХХH все ж прогресує і ШКФ опускається нижче 45 мл/ хв, додаються порушення роботи інших органів, наприклад анемія, пов'язані з XXH порушення обміну кальцію і зміни скелета, зміни серцевосудинної системи, кишечника та інших органів. Тактика лікування залежать від конкретної причини виникнення анемії. Якщо анемія зумовлена хворобою нирок, схема лікування міститиме наступні складові. Препарати групи стимуляторів еритропоезу (CE) CE стимулюють утворення в організмі червоних кров'яних тілець. Зазвичай CE вводять у вигляді ін'єкцій під шкіру (підшкірна ін'єкція) у кабінеті лікаря. n Препарати заліза Залізо також потрібне організму для побудови червоних кров'яних тілець, особливо, якщо вам призначено CE. За відсутності достатньої кількості заліза застосування CE неефективне. Залізо можна вживати всередину у вигляді таблеток, або вводити безпосередньо в вену в кабінеті лікаря або у лікарні.
Висновок. В останні роки ми все сильніше усвідомлюємо протиріччя між біологічною природою людини, яка залишається незмінною протягом десятків і сотень тисяч років, і все більш швидкою зміною середовища, в якому людина живе. Загалом, усі мінерали, присутні в нашому організмі, необхідні для підтримки здоров'я. Певні кількості кожного з них допомагають організму підтримувати баланс в обміні речовин, вони $€$ неодмінною складовою всіх важливих для життя процесів. Для побудови червоних кров'яних тілець організм потребує заліза. Після початку прийому СЕ утворення червоних кров'яних тілець зросте, тому наявні запаси заліза використовуватимуться швидше. Якщо не вживати препарати заліза, лікування СЕ буде неефективним. Контроль добового споживання та корекція рівнів калію, сірки, магнію, хлору та заліза є невід'ємними складовими впродовж всього життя людини, і вкрай необхідними у населення різних вікових груп, яке мешкає на територіях, радіоактивно забруднених внаслідок аварії на ЧАЕС, особливо у осіб з віковими змінами нирок.

Перспективи. Корекція дисмікроелементозів $€$ профілактикою розвитку захворювань впродовж життя людини.

\section{ЛITEPATУРA}

1. Здоровое питание для взрослых. Информационный бюллетень. 2015. № 394. URL: $\quad$ http://www.who.int/mediacentre/ factsheets/fs394/ru/

2. Москаленко В.Ф. Пріоритетні напрями протидії глобальним загрозам громадському здоров'ю та міжнародна безпека в охороні здоров'я // Охорона здоров'я України. 2007. - № 1(25). - С. 9-11.

3. Грузєва О.В., Іншакова Г.В., Яковенко В. Г. Вплив харчових чинників на здоров'я населення // Главный врач. - 2008. - № 11. C. 71-72.

4. Comparative analysis of nutrition policies in the WHO European Region / A comparative analysis of nutrition policies and plants of action in Who European Member states, May 2006. - URL: http://www.euro.who.int/ data/assets/pdf_file/0004/149782/inst ambul_ conf_20ebd02.pdf.

5. Мурашко В. О., Рущак Л. В. Раціональне, лікувально-профілактичне та лікувальне харчування як засіб радіаційного захисту на сучасному етапі ліквідації наслідків чорнобильської аварії // Радіологічний вісник. 2014. - № 2. - С. 28-29.

6. Гуліч М.П. Раціональне харчування та здоровий спосіб життя - основні чинники збе- 
реження здоров'я населення // Проблемы старения и долголетия. - 2011. - Т. 20, № 2. - С. 128-132.

7. Рингач Н.О. Громадське здоров'я як чинник національної безпеки: монографія. - К.: НАДУ, 2009. - 296 с.

8. Shrimpton D.H. Nutritional implications of micronutrients interactions / D.H. Shrimpton // Chemist and Druggist. - 2004. - 15 May. P. 38-41.

9. Sandström B. Micronutrient interactions: effects on absorption and bioavailability / Brittmarie Sandström // British Journal of Nutrition. 2001. - Vol. 85, Suppl. 2. - P. 181-185.

10. Микронутриенты в питании здорового и больного человека / В.А. Тутельян, В.Б. Спиричев, Б.П. Суханов, В.А. Кудашева. М.: Колос, 2002. - 424 с.

11. Ребров В. Г., Громова О. А. Витамины, макро- и микроэлементы. М.: ГЭОТАР-Медиа, 2008. 960 c.

12. Скальный А.В. Химические элементы в физиологии и экологии человека. / М.: Оникс 21 век, 2004. - 216 с.

13. Нанотехнології мікронутрієнтів: проблеми, перспективи та шляхи ліквідації дефіциту макро- та мікроелементів / А.М. Сердюк, М.П. Гуліч, В.Г. Каплуненко, М.В. Косінов // Журнал Національної академії медичних наук України. - 2010. - Т. 16, № 1. - С. 107-114.

14. Скальный А.В. Микроелементы: бодрость, здоровье, долголетие / М.: Эксмо. - 2010. $288 \mathrm{c}$.

15. Стрейн Дж. Микронутриенты: вопросы питания и хронические болезни // Вопр. питания. - 2000. - №3. - С. 43-45.

16. Рогинская Н.Ф., Богданец Е.С. Проблемы недостатка микроэлементов в питании современного человека и перспективы их преодоления // Наукові праці. - 2014. - Вип. 46, T. 1. - C. 187-191.

17. Богатырев А.Н., Пряничникова Н.С., Макеева И.А. Натуральные продукты питания - здоровье нации // Пищевая промышленность. - 2017. - №8. - С. 26-29.

18. Погожева А.В., Батурин А.К. Питание и профилактика неинфекционных заболеваний. Beau Bassin: Lambert Academic Publishing, 2017. - 184 c.

19. Нутріціологічна характеристика харчування вагітних жінок, які мешкають на радіоактивно забруднених територіях України / I.T. Матасар, В.І. Матасар, Л.А. Горчакова, Л.М. Петрищенко, О.Г. Луценко // Науковий вісник Національного медичного університету ім. О.О. Богомольця. 2010. № 2-3. С. 62-68.
20. Мікронутрієнти як чинники розвитку преморбідних та морбідних станів у населення, що мешкає на радіоактивно забруднених територіях / І.T. Матасар, Л.А. Горчакова, Л.М. Петрищенко, В.І. Матасар // Проблеми радіаційної медицини та радіобіології. 2007. Вип. 13. С. 239-245.

21. Корекція есенціальних нутрієнтних дефіцитів серед дітей та підлітків як засіб профілактики аліментарних та аліментарно залежних станів / I.T. Матасар, B.I. Берзінь, B.I. Матасар, О.Г. Луценко // Семейная медицина. 2014. № 2(52). С. 139-142.

22. Щербак В.А., Каргина И.Г., Щербак Н.М. Маркеры метаболизма костной ткани при рахите // Российский вестник перинатологии и педиатрии. - 2020. № 65 (4). - С. 71-77.

23. Майданник В. Г. Рахит у детей : современные аспекты. - Киев, 2006. - 114 с.

24. Коровина Н.А., Захарова И.Н., Чебуркин А.В. Нарушения фосфорно-кальциевого обмена у детей. Проблемы и решения: руководство для врачей. М.: 2005 - 70 с.

25. Спиричев В. Г. Витамины и минеральные вещества в питании и поддержании здоровья детей. М.: [б. и.], 2007. 22 с.

26. Погожева А.В. Значение макро- и микроэлементов пищи в оптимизации минеральной плотности костной ткани // Consilium Medicum. - 2015. - № 2, T. 17. - С. 61-65.

27. Витебская А.В., Смирнова Г.Е., Ильин А.В. Витамин D и показатели кальций-фосфорного обмена у детей, проживающих в средней полосе России, в период максимальной инсоляции // Остеопороз и остеопатии. 2010. № 2. C. 4-9.

28. Коровина Н.А., Захарова И.Н., Чебуркин А.В. Нарушения фосфорно-кальциевого обмена у детей. Проблемы и решения: руководство для врачей. М.: $2005-70$ с.

29. Поліщук Т.В., Гуліч М.П., Карпенко Л.О. Гігієнічна оцінка особливостей мікронутрієнтного складу молока та традиційних кисломолочних продуктів вітчизняного виробництва // Гігієна наслених місць. 2012. - Вип. 60. - С. 229-236.

30. Кандинская Е.С., Редькин С.В., Чебакова Г.В. Мониторинг содержания кальция в сыром молоке коров // Ветеринария сегодня. - 2019. - № 1. - С. 29-33. URL: h t t p s://doi.org/10.29326/2304 196X-2019-1-28-29-33

31. Беневоленская Л.И., Никитинская О.А., Торопцова Н.В. Фармакологическая профилактика первичного остеопороза // РМЖ. 2008. - № 6, T. 16. - C. 409-414. 
32. Кукс В.Г., Тутельян А.А. Витамины и микроэлементы в клинической фармакологии. М.: Палея, 2001. - 214 с.

33. Fenech M., Fergason L.R. Vitamin/minerals and genomic stability in humans // Mutat. Res. - 2001. - N 475. - P. 1-6.

34. Защитное действие витаминов при индуцированном мутагенезе / А.Д. Дурнев, Е.С. Сиднева, А.К. Жанатаев и др. // Вестн. Poc. AMH. - 2006 - № 7. - C. 6-13.

35. Скальный А.В., Быков А.Т., Яцык Г.В. Микроэлементы и здоровье. Москва. 2002. $133 \mathrm{c}$.

36. Спасов А. А. Магний в медицинской практике. - Волгоград, 2000. - 268 с.

37. Громова О. А. Его величество магний: учеб.метод. пособие. - М., 2000. - 53 с.

38. Громова O.A. Значение дефицита магния в организме ребенка с позиции практического врача // Рос. Педиатр. Журн. - 2002. № 5. - C. 16-21.

39. Громова O.A. Роль и значение магния в патогенезе заболеваний нервной системы // Неврология и психиатрия им. С.С. Корсакова. - 2002. - № 12. - С. 45-49.

40. Стресс у детей и подростков: причины и последствия, лечение и профилактика / Е.С. Акарачкова, С.В. Вершинина, О.В. Котова, И. В. Рябоконь. М.: [б. в.], 2015. - 19 с.

41. Громова О.А. Магний и пиридоксин: основы знаний. М. 2006.179 с.

42. Акарачкова E.C. Роль дефицита магния в формировании клинических проявлений стресса у женщин // Проблемы женского здоровья. - 2013. - № 3. Том 8. - С. 25-32.

43. Научные основы здорового питания / В.А. Тутельян, А. И. Вялков, Л. Н.Разумов и др. М.: Панорама, 2010. 536 с.

44. WHO. Iron deficiency anemia: Assessment, prevention and control. - Geneva, 2001. $114 \mathrm{p}$.

45. Железодефицитная анемия: современные подходы к диагностике и лечению / С.Н. Гайдукова, С.В. Выдыборец, Л.А. Сивак, T.C. Ширинян. - К.: Здоров'я, 2003. - 32 с.

46. Проблеми профілактики, діагностики та лікування залізодефіцитних анемій в умовах дії малих доз іонізуючого випромінювання / В.Г. Бебешко, І.Т. Матасар, В.І. Матасар, О.Г. Луценко // Проблеми харчування. 2012. - № 1-2. - С. 19-29.
47. Постникова С.Л., Малышева Н.В., Касатова Т.Б. Клинические рекомендации по коррекции железодефицита у различных групп пациентов // Русский медицинский журнал. - 2010. - Т. 18, № 30. - С. 1843-1848.

48. Свободнорадикальные процессы у больных железодефицитной анемией на фоне лечения препаратами железа / Л.И. Дворецкий, Е.А. Заспа, П.Ф. Литвицкий, С.Б. Болевич и др. // Терапевтический архив. - 2006. №78(1). - C. 52-57.

49. Сравнительная эффективность двух терапевтических планов лечения железодефицитной анемии у детей и подростков / E.A. Ожегов, И.С.Тарасова, А.М. Ожегов, B.M. Чернов и др. // Вопросы гематологии, онкологии и иммунопатологии в педиатрии. - 2005. - № 4 (1). - С. 21.

50. Бебешко В.Г., Бруслова К.М. Полидефицитные анемии у детей // Доктор. - 2003. № 6. - C.70-73.

51. БебешкоВ.Г., БрусловаК.М.Залізодефіцитні стани у підлітків // Український журнал гематології та трансфузіології. -2003. - № 2. C. 10-16.

52. Grobbee D.E., Roest M. Serum ferritin is a risk factor for stroke in postmenopausal women // Stroke. - 2005. - № 36(8). - P. 1637-1641.

53. Shrimpton D.H. Nutritional implications of micronutrients interactions // Chemist and Druggist. - 2004. - Vol. 15. - P. 38-41.

54. Горбачев В.В., Горбачева В.Н. Витамины. Микро- и макроэлементы. Справочник. Минск: «Книжный Дом», 2002. - 445 с.

55. Залізодефіцитні анемії у дорослих і дітей. Особливості перебігу та шляхи аліментарної корекції в умовах дії малих доз іонізуючого випромінювання на інших негативних чинників доUАвкілля: монографія / За ред. В. Г. Бебешка та І. Т. Матасара. - Київ, 2012. - 184 c.

56. Научные основы здорового питания / В.А. Тутельян, А. И. Вялков, Л. Н. Разумов и др. М.: Панорама, 2010. 536 с.

57. Никула Т.Д., Красюк І.В., Красюк Е.К. (54) Спосіб корекції дисмікроелементемії // UA 999105946 16.04.2001. Бюлетень № 3, 2001. 


\section{PЕЗЮME}

\section{ЭССЕНЦИАЛЬНЫЕ МИНЕРАЛЬНЫЕ ВЕЩЕСТВА КАК СРЕДСТВА КОРРЕКЦИИ ПИЩЕВОГО СТАТУСА НАСЕЛЕНИЯ, ПРОЖИВАЮЩЕГО НА ТЕРРИТОРИЯХ, ЗАГРЯЗНЕННЫХ ВСЛЕДСТВИЕ АВАРИИ НА ЧАЭС \\ (Материалы подготовлены к 35-летию аварии на Чернобыльской атомной электростанции 26.04.86 р.)}

'Матасар И.Т., ${ }^{2}$ Мойсеенко В.А., 'Петрищенко Л.М., 1 Чернышов А.В.

1 ДУ «Национальный научный центр радиационной медицины Национальной академии медицинских наук Украины», ${ }^{2}$ Национальний медицинский университет имени А.А. Богомольца Киев, Украина

Введение. Данная работа посвящена проблеме нарушения питания населения различных возрастных групп, проживающего на территориях, радиоактивно загрязненных вследствие аварии на ЧАЭС, в частности недостаточном содержании в частности, недостаточного содержания макроэлементов (калия, серы, магния, хлора) и микроэлементов (железа).

Цель. Обобщение сведений о свойствах о свойствах эссенциальных минеральных веществ, в частности, калия, хлора, магния, железа, их суточное потребление населением различных возрастных групп, проживающего на территориях, радиоактивно загрязненных вследствие аварии на ЧАЭС.

Материалы и методы. Библиографический - проведен теоретический анализ и осуществлено обобщение данных литературы, проанализированы фактическое содержание макро- и микроэлементов в рационах питания различных возрастных групп населения (взрослого трудоспособного, детского) из разных населенных пунктов Иванковского района Киевской области, проживающего на территориях, радиоактивно загрязненных вследствие аварии на ЧАЭС в течение 2004-2018 гг. При исследовании использованы анкетно-опросный, математический и статистический методы.

Результаты и их обсуждение. Особую роль в физиологически оптимальном функционировании организма играют минеральные вещества, которые на уровне других ингредиентов пищи формируют ткани живого организма, входят в состав энзимов и коэнзимов, гормонов, принимая участие в процессах образования энергии, роста и восстановления организма. Образование ферментов и реакции с их участием происходят с обязательным участием минеральных веществ. У больных хронической болезнью почек, анемия может привести к серьезным проблемам, осложнить течение других заболеваний. Уменьшение количества гемоглобина и (или) эритроцитов на фоне сниженного уровня железа сопровождается увеличением нагрузки на сердце. Это приводит к развитию гипертрофии левого желудочка (ГЛЖ). К сожалению, у многих пациентов с болезнью почек ГЛЖ возникает задолго до того, как развивается почечная недостаточность. Иногда ГЛЖ даже становится причиной смерти таких больных. Раннее лечение анемии помогает предотвратить развитие этого заболевания и многие другие серьезные ослож- нения. Имеющийся дисмикроэлементоз требует диагностики и коррекции.

Выводы. Контроль суточного потребления и коррекция уровня макроэлементов (калия, серы, магния, хлора) и других эссенциальных минеральных веществ (в частности, железа) являются неотъемлемыми составляющими на протяжении всей жизни человека, и крайне необходимыми у населения различных возрастных групп, проживающего на территориях, радиоактивно загрязненных вследствие аварии на ЧАЭС, особенно у лиц с возрастными изменениями почек.

Ключевые слова: состояние питания, радиоактивно загрязненные территории, калий, сера, магний, хлор, железо, возраст, почки.

\section{SUMMARY}

ESSENTIAL MINERAL SUBSTANCES AS MEANS OF CORRECTING THE FOOD STATUS OF THE POPULATION OF CONTAMINATED TERRITORIES DUE TO THE CHERNOBYL CATASTROPHE

(Materials prepared for the 35th anniversary of the accident at the Chernobyl nuclear power plant 26.04.86)

${ }^{1}$ Matasar I.T., ${ }^{2}$ Moyseyenko V.O., ${ }^{1}$ Petrishchenko L.M., ${ }^{1}$ Chernyshov A.V.

${ }^{1} \mathrm{SI}$ "National Research Center for Radiation Medicine National Academy of Medical Sciences of Ukraine", ${ }^{2}$ Bogomolets National Medical University Kyiv, Ukraine

Introduction. This work is devoted to the problem of malnutrition of the population of different age groups living in territories radioactively contaminated after the Chernobyl accident, in particular, the insufficient content of calcium and phosphorus.

Goal. Generalization of information about the properties of several minerals (potassium, sulfur, magnesium, chlorine, iron), in particular, calcium and phosphorus, their daily consumption by the population of different age groups living in territories radioactively contaminated as a result of the Chernobyl accident.

Materials and Methods. Bibliographic - a theoretical analysis was carried out and the literature data were generalized, the actual content of macronutrients in the diets of various age groups of the population (working-age adult, children) from different settlements of the Ivankovsky district of the Kiev region, living in territories radioactively contaminated after the Chernobyl accident, was analyzed during 2004-2018. Questionnaire, mathematical and statistical methods were used in the study.

Results and discussion. In patients with chronic kidney disease, anemia can lead to serious problems, and may complicate the course of other diseases. A decrease for hemoglobin and (or) erythrocytes is accompanied by an increase in the load on the heart. This leads to the development of left ventricular hypertrophy (LVH). Unfortunately, in many patients with kidney disease, LVH occurs long before renal failure develops. Sometimes LVH even causes the death of such patients. Early treatment of anemia helps to prevent the development of this disease and many other serious complications. Existing dysmicroelementosis needs diagnosis and correction. 
Conclusions. Control of daily consumption and correction of levels of potassium, sulfur, magnesium, chlorine and iron, which are integral components throughout a person's life, and are extremely necessary for the population of various age groups living in territories radioactively contaminated after the Chernobyl accident, especially for people with age-related changes in the kidneys.

Key words: nutritional status, radioactively contaminated areas, potassium, sulfur, magnesium, chlorine, iron, age, kidneys.

\section{АВТОРСЬКА ДОВІДКА}

\section{Матасар Ігнат Тимофійович}

Ду “Національний науковий центр радіаційної медицини Національної академії медичних наук України", академік НАН ВО України,

д.м.н., професор

моб.: +380674662818:

E-mail: matasar.it@gmail.com

\section{Мойсеєнко Валентина Олексіївна}

Національний медичний університет імені О.О. Богомольця,

академік НАН ВО України,

д.м.н., професор

моб.: +380677779249:

E-mail: moyseyenko_vo@ukr.net ORCID ID:0000-0003-1402-6028

\section{Петрищенко Людмила} Миколаївна

ДУ “Національний науковий центр радіаційної медицини Національної академії медичних наук України", к.б.н.

моб.: +380958753439

E-mail: luda_p@email.ua

\section{Чернишов Андрій Вікторович}

ДУ “Національний науковий центр радіаційної медицини Національної академії медичних наук України", K.M.H, C.H.C

моб.: +380968519192

E-mail: matasar.it@gmail.com

\section{Матасар Игнат Тимофеевич}

ГУ «Национальный научный центр радиационной медицины

Национальной академии медицинских наук Украины»,

академик НАН ВО Украины,

д.м.н., професор

моб.: +380674662818

E-mail: matasar.it@gmail.com

\section{Мойсеенко Валентина Алексеевна}

Национальный медицинский университет имени А.А. Богомольца, академик НАН ВО Украины,

д.м.Н., профессор

моб.: +380677779249:

E-mail: moyseyenko_vo@ukr.net

ORCID ID:0000-0003-1402-6028

\section{Петрищенко Людмила Николаевна}

ГУ «Национальный научный центр радиационной медицины Национальной академии медицинских наук Украины», к.б.н.

моб.: +380958753439

E-mail: luda_p@email.ua

\section{Чернышов Андрей Викторович}

ГУ «Национальный научный центр радиационной медицины Национальной академии медицинских наук Украины», K.M.H, C.H.C

моб.: +380968519192

E-mail: matasar.it@gmail.com

\section{Matasar Ignat}

SI "National Research Center for Radiation Medicine

National Academy of Medical Sciences of Ukraine ",

$\mathrm{MD}, \mathrm{PhD}$, Professor

mob.: +380677779249

E-mail: matasar.it@gmail.com

\section{Moyseyenko Valentyna}

Bogomolets National Medical University, $\mathrm{MD}, \mathrm{PhD}$, Professor mob.: +380677779249:

E-mail: moyseyenko_vo@ukr.net ORCID ID:0000-0003-1402-6028

\section{Petrishchenko Liudmyla}

SI «National Research Center for Radiation Medicine National Academy of Medical Sciences of Ukraine» PhD

E-mail: luda_p@email.ua

\section{Chernyshov Andrii}

SI «National Research Center for Radiation Medicine National Academy of Medical Sciences of Ukraine» $\mathrm{MD}, \mathrm{PhD}$

mob.: +380968519192

E-mail: matasar.it@gmail.com

Стаття надійшла до редакції 27.09.2021 p. 